\title{
Sosyal Desteğin Birey Yaşamında Önemi ve Sosyal Hizmet ${ }^{1}$
}

\author{
Sümeyye Beyza Abay Alyüz ${ }^{2}$
}

\begin{abstract}
Özet
Sosyal desteğin insan yaşamı için önemi yaşamın ilk anından itibaren ele alınmaktadır. Bireyin sosyal ilişkilerinin farkında olması ile sosyal destek ihtiyacının arttığ söylenebilir. Nitekim yaşamın belli dönemlerinde özellikle üzüntü, kaygı zamanlarında sosyal destek bireyin yaşamını iyileştirici, rahatlatıcı öneme sahiptir. Sosyal destek sıklıkla hastalık dönemi, psikolojik sorunlar, bireylerin karşılaştıkları sosyal sorunlarla birlikte ele alınsa da, bireyin genel iyilik haline de etkisi vardır.

Sosyal destek, hem bireylerin yaşamış oldukları bir sosyal sorunda hem de yaşamlarındaki genel iyilik halinin sürdürülmesinde sosyal çevrelerinden (sosyal kaynaklarından) elde etmiş oldukları duygusal destek, maddi ve araçsal yardımlar ve bilgi desteği olarak tanımlanabilir.

Sosyal desteğin bireyin yaşamındaki öneminin anlaşılması öncelikle bu desteklerin neler ve hangi etkileri olduğu sorusunun aydınlatılması ile olacaktır. Diğer yandan bireylerin sosyal destek kaynaklarının kimler olduğu ise, hem elde edilen sosyal desteğin boyutunu etkileyen hem de sosyal destek potansiyelinin ortaya konulması ve geliştirilmesi için insan yaşamının iyiliğini konu alan bir disiplin ve de bir meslek olan sosyal hizmet gibi alanlar için bir firsat sunacaktır.

Bu çalışmada, sosyal sermaye ve sosyal ağ teorilerin sağladığı perspektifle sosyal destek ele alınmıştır. Sosyal destek, sosyal sermaye, sosyal ağ ilişkisinin sosyal hizmet uygulamasına ne kattığı irdelenmiştir. Çalışmanın amacı, sosyal hizmet uygulamasında sosyal desteğin analiz edilmesinde model oluşturulmasına katkı sağlamaktır.
\end{abstract}

Anahtar Kelimeler: Sosyal Destek, Sosyal Sermeye, Sosyal Hizmet, Sosyal Ağlar

1 Bu makalede, 2018 y1lında sunulan "SOSYAL SERMAYE, SOSYAL AĞLAR ve SOSYAL DESTEK İLİŞKİSI-Sultanbeyli ve Kadıköy’de Sosyal Hizmet Merkezlerine Başvuranlara İlişkin Karşılaştırmalı Durum Çalışması-“" adlı doktora tezinin verilerinden yararlanılmıştır.

2 Yetkilendirilmiş yazar: Sağlık Bilimleri Üniversitesi, Sosyal Hizmet Bölümü, sbeyzaabay@ gmail.com, Orcid ID: 0000-0002-5974-4560, ORCID ID: 0000-0002-5974-4560 


\title{
The Importance of Social Support in the Life of Individuals and Social Work
}

\author{
Sümeyye Beyza Abay Alyüz
}

\begin{abstract}
The importance of social support for human life is addressed from the very first moment of life. It can be said that the need for social support increases with the individual'sawareness of his/her social relations. As a matter of fact, in certainperiods of life, especially in times of sadness and anxiety, social support has a healing and comforting importance for an individual's life. Although social support is often addressed with the period of illness, psychological problems, and social problems that individualsface, it also has an impact on the individual's general well-being.

Social support can be defined as the emotional support, financial and instrumental aids and information support that they have obtained from their social circles (social resources) both in a social problem experienced by individuals and in maintaining the general well-being in their lives.

Understanding the importance of social support in an individual's life will occurprimarily by clarifying the questions of what these supports are and what effects these supports have. On the other hand, knowing who are the source of social support for individuals will provide an opportunity for are as such as social work which is a discipline and a profession that affects the size of the obtained social support and is about the well-being of human life for the development of social support potential.

In this study, social support is discussed with the perspective provided by social capital and social network theories. What social support, social capital, social network relationship adds to social work practice is examined. The aim of the study is to contribute to setting a model in the analysis of social support in social work practice.
\end{abstract}

\section{Keywords}

Social Support, Social Capital, Social Work, Social Networks 


\title{
أهمية الدعم الاجتماعي في الحياة الفردية والخدمة الاجتماعية \\ سمية بيضاء آباي آليوز
}

\begin{abstract}
ملخص

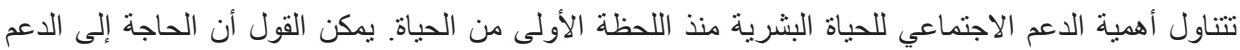

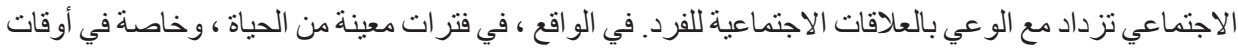

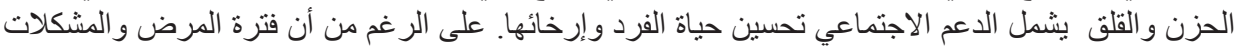

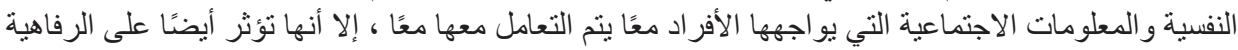
العامة للفرد.

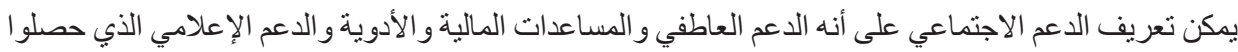

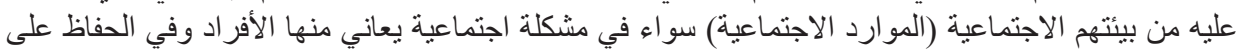

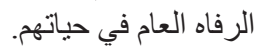

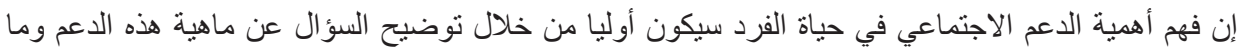

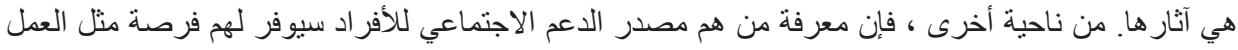

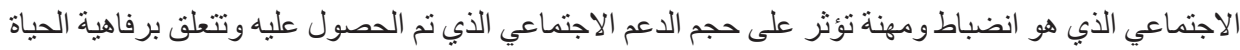
البشرية لتطوير إمكانات الدعم الاجنماعي.

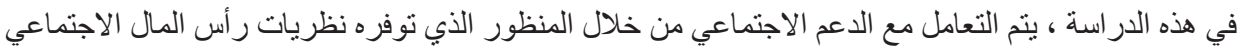

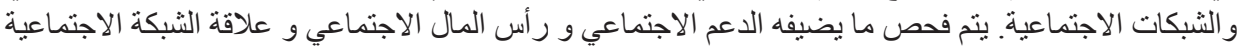
إلى تطبيق العمل الاجنماعي. الهدف من الدراسة هو المساهمة في النمذجة في تحليل الدعم الاجنماعي في تطبيق الاعليق الخدمة الاجتماعية.
\end{abstract}

\section{الكلمات المفتاحية}

الدعم الاجتماعي، رأس المال الاجتماعي، الخدمة الاجتماعية، الثبكات الاجتماعية

\section{Giriş}

Sosyal desteğin bireyin yaşamına etkilerini inceleyebilmek ya da ortaya koyabilmek için, bu desteğin kimler tarafından sağlandığı, ne tür destekler sağladığı, hangi etkilere sahip olduğu sorularının öncelikle aydınlatılması gerekir. Bu soruların cevabı sosyal ağ- sosyal destek- sosyal sermaye ilişkisinin ve teorik bakış açısının sentezlenmesi ile ortaya konabilir.

Öncelikle sosyal desteğin kimler tarafından sağlandığı konusu literatürde birkaç kavramla birlikte incelenir. Sosyal desteği kim sağlıyor sorusunun cevabı; sosyal ağlar veya sosyal destek mekanizmaları olabilir. Sosyal desteğin sosyal ilişkiler içinde elde edilmesi "kimler tarafından sağlanıyor" sorusunun önemini gösterir. 
Sosyal ağ (social network) kavramı, bireyin çevresinde ilişki kurduğu bireyleri niteler. Sosyal destek mekanizmaları (Social support mechanisms) ise, bireyin çevresinden sosyal destek sağladığı bireyleri nitelemektedir. Sosyal desteğin kimler tarafından sağlandığ 1 , bireyin elde edeceği sosyal destek potansiyelini etkilemektedir. Sosyal ağlar, sosyal destek potansiyelinin belirlenmesinde en önemli etkenlerden biridir. Sosyal destek- sosyal ağ teorik perspektifi bu anlamda sosyal destek potansiyelini etkileyen değişkenlerin belirlenmesinde ve insan yaşamını ne ölçüde etkilediği konusunun aydınlatılmasında önemli bir paya sahiptir. Sözgelimi, sosyal desteğe "kim” sorusu üzerinden yaklaşmak sosyal ağ teorisyenlerinin perspektifiyle mümkün olmaktadır.

Sosyal sermaye ve sosyal destek bireyin sosyal ilişkileri üzerinden ya da sosyal ilişkiler içinde elde ettikleri kazanımlardır. Elde edinilen sosyal destek türüne göre bireyin iyilik haline farklı etkileri olmaktadır. Sosyal sermaye ve sosyal destek teorisyenleri elde edilen kazanımların birey yaşamına etkilerini ele almışlardır. "Sosyal desteğin insan yaşamındaki etkileri" sosyal sorunla karşılaşan birey için yaşamını iyileştirici, iyilik halini geliştirici etkilere sahip olduğu gibi, hayatında engellere yol açan veya sosyal işlevsizliğe neden olan bir sosyal sorunla karşılaşmayan birey için de iyilik halini geliştirici, yaşam doyumunu arttıran etkiye sahiptir. Sosyal destek teorisyenlerinin yaklaşımı ile kavramsallaştırıldığında, sosyal desteğin bireyin yaşamına yaşamını iyileştirici "direkt etki” ye sahip olduğu gibi, sorunla arasında "tampon” görevi görerek sorunu iyileştirici, sorunun zararlı etkilerini azaltan bir etkiye sahiptir. Diğer yandan sosyal desteğin önleyici etkisinden de bahsedilmektedir. Bu durumda sosyal destek, stres durumlarının oluşmasını engellenmesinde de bir etkiye sahiptir.

Çalışmada irdelenecek bu durumlar insan yaşamını konu alan bir disiplin olan, aynı zamanda insan yaşamını iyileştirici, sorunların önlenmesini ve çözülmesinde yardımı amaç edinen bir meslek olan sosyal hizmet için ayrı bir öneme sahiptir. Sosyal hizmetin "genelci yaklaşım" içinde" çevre içinde birey" yaklaşımı, hem soruna etki eden nedenlerin belirlenmesinde hem de sorunun çözümüne etki eden nedenlerin, etkenlerin belirlenmesinde çoklu müdahale düzeyine işaret eder. Bu yaklaşım, sosyal hizmet alanında benimsenen "güçlendirme yaklaşımı"ile birlikte ala alındığında ise sosyal destek kaynaklarının belirlenmesinin ve çözüme dâhil edilmesinin sosyal hizmet müdahalesi açısından önemini göstermektedir.

\section{Sosyal destek nedir?}

Sosyal desteğe zemin hazırlayan araştırmalar şu soruyla başlamıştır: bireyler neden yaşadıkları olaylara psikolojik ve fiziksel olarak farklı tepki vermektedirler? Bu soruya bazı araştırmacılar, psikolojik mekanizmalara odaklanarak cevap vermişlerdir. Onlara göre, bireylerin problemlerle başa çıkması onların bireysel becerilerine bağlıdır. Diğer araştırmacı grup ise, bireyin sahip olduğu sosyal ilişkilerle (sosyal kaynakları) bağlantı kurmuştur. Onlara göre, bireyin sahip olduğu ağların fonksiyonu olarak elde ettikleri sosyal destek zor durumları ile mücadelede onları güçlendirmektedir (Paulinger, 2012: 70). Bu durum bizlere bireylerin zor durumda mücadele etmelerinde psikolojik 
durumlarının önemini gösterdiği gibi, diğer yandan bireylerin psikolojik durumunu etkileyen sosyal desteğe de ayrı bir önem atfetmektedir.

Sosyal destek konusunda bireyin özellikle zor durumlarında örneğin kronik hastalık durumlarıyla, bireyin yaşamış olduğu stresli ve problematik durumlarla, psikolojik durumlarıyla bir ilişki kurulduğu görülmektedir. Bunun yanında sosyal desteğin yaşam doyumuna, bireyin genel iyilik haline etkisinin ele alındığ 1 görülmektedir. Özellikle son zamanlarda sosyal destek üzerine yapılan araştırmalara bakıldığında, sosyal desteğin bireyin genel iyilik haline vurgu yapan araştırmalara rastlanmaktadır.

Literatüre bakıldığında 1970'li yıllarda sosyal destek literatürdeki yerini almıştır. Cassel (1976) makalesinde, sosyal çevrenin ve sosyal desteğin bireyin stresle ve olumsuz durumlarla başa çıkmadaki etkisinden bahsetmektedir. Cassel insan sağlının devamı için psiko- sosyal süreçlerin önemini vurgulamıştır. Pfingstmann’a göre (1987: 77) sosyal destek bireyin özellikle desteğe ihtiyacı olduğu zor zamanlarında bağlantıda olduğu kişilerden (eşi, ailesi, arkadaşları, komşusu, iş arkadaşları, din görevlisi) kullanıma hazır olan yardımdır.

House, sosyal desteği 4 başlıkta incelemiştir. Öncelikle sevgi, saygı empatiyi vb. içeren duygusal destek, daha somut yardımları içeren araçsal destek, çevre üzerinden sağlanan bilgi desteği ve kişinin kendi hakkında sosyal çevresi üzerinden aldığı bilgi ile kendini değerlendirme imkânı sunan geri bildirim desteğidir (House, 1981: 44). Linn (1986: 20) ise sosyal sermaye teorisi ile bağlantılı olarak sosyal desteği iki boyutta ele almıştır; belirli bir amaca yönelik örneğin iş bulmak, borç para vermek, bebek bakıcısı bulmak gibi araçsal destek, anlamsal destek ise ilişkilerde duyguların paylaşılması, problemleri istişare etmek, farklı sorunları tartışmak ve aynı zamanda House'un duygusal destek ve öz değerlendirme desteği olarak nitelendirdiği ilişkiler içerisinde değer görmek gibi birtakım destekleri kapsar (Paulinger, 2012: 70).

Sommer/ Fydrich (1989) sosyal destek konseptini, bireylerin sosyal ilişkilerinden ve etkileşimlerinden hangi ölçüde destek, yardım, yarar algıladığı ve bireyi nasıl etkilediği şeklinde ele almıştır. Laireiter'e göre, sosyal destek sosyal ilişkilerin önemli bir fonksiyonudur. Bu sayede duygusal ve sosyal ihtiyaçlar giderilir. Bu duygusal ve sosyal temel ihtiyaçlar arasında, ait olma, yakınlık, güvenlik, pratik yardım ve duygu vardır (Eisenberger, 2010: 15). Sosyal desteğin tanımlarına bakıldığında, sosyal desteğin duygusal boyutu, araçsal boyutu ve bilgi boyutu vurgulanmaktadır. (Erlemeier, 1995; Kaufmann, 1989; Unger, Powell, 1980)

\section{Sosyal Desteğin Etkileri}

Sosyal desteğin bireylerin hayatı içerisindeki etkisi iki grupta incelenmektedir:

1. Direkt etkisi bireyin genel iyilik haline etkisidir. Bu bakımdan sosyal desteğin ana etkisi ya da direkt etkisi olarak nitelendirilmektedir.

2. Tampon etkisinde ise sosyal desteğin daha spesifik durumlar için olan etkisinden bahsedilmektedir. Sosyal desteğin bu etkisi özellikle kriz durumlarının hafiflemesini ya 
da krizin ortadan kaybolmasını sağlar. Sosyal desteğin tampon etkisi böylece, bireyin zor durumlarındaki stresini azaltan, moral duygusu veren ve problemi ile başa çıkmada ona destek sağlayan bir güç olarak anlaşılmaktadır (Bullinger ve Nowak, 1998: 105). Bir kriz durumunda, sosyal destek aracılı̆̆ıyla negatif etkiler ya azalır ya da bu etkilerden tamamen kaçınılabilir (Eisenberger, 2010: 16). Bu durumda sosyal destek stres ve kriz durumlarında bir tampon görevi görür.

Direkt etkisinde temel görüş, sosyal desteğin bireyin temel ve durumlara bağlı olmayan ihtiyaçlarını giderdiği ve bireyin ruh hali üzerinde direkt etkisi olduğudur. Direkt etkisinde kasıtlı olmayan, planlanmamış, olağan sosyal destek anlaşılmaktadır, aslında bu sosyal ilişkilerin kendi varlığı içinde genel rol ilişkilerinde ve insanlar arası etkileşimde günlük sosyal yaşamın birey üzerindeki direkt ve sürekli desteğidir. Bu durumda sosyal destek, ne bireyin kendisinin elde ettiği destektir ne de sosyal ağında kontakta bulunduğu kişinin ona belirli bir sorun için sunduğu yardımdır. Bu yüzden sosyal destek, belirli somut stresli yaşam koşulları olmadan da etkili olabilir. Tampon etkisi ise, direkt etkisinin aksine, spesifik olarak güçlük durumu oluşturan durumlarla sosyal desteği sınırlar. Sosyal destek, güçlük oluşturan durumlarda stres kaynakları ile tampon görevi görür ve bir yandan duruma dair algıyı ve yorumu diğer yandan problemin büyüklüğünü ve niteliğini etkilemeye çalışır (Barth, 1998: 17- 18). Direkt etkisi daha temel insani ihtiyaçlarla ilgilidir; aitlik, değer görme buna örnek olarak gösterilebilir. Tampon etkisi ise belli stres durumları için geçerlidir, sağlık, iş sorunu, kişisel problemler bireyin iyilik halini zedeler ya da tamamen etkiler (Diewald ve Sattler, 2010: 694).

Diewald ve Sattler (2010: 694) sosyal desteğin direkt etkisi ve tampon etkisinden başka önleyici etkisini de ele almıştır. Sosyal desteğin öneyici etkisinden sosyal destek stres durumlarının oluşmasını engellenmesi veya onun boyutunu azaltması durumunda bahsedilebilir. Örnek olarak nesilden nesile geçe ekonomik miras verilebilir. Materyal desteğin bu etkisi ile bireyler ekonomik dar boğaz ya da hayata tutunabilme korkusu yaşamazlar.

\section{Sosyal Desteğe Teorik Bakış}

Sosyal desteğin birey için önemini anlamlandırmada birkaç sorunun öncelikle aydınlatılması gerekmektedir.

- Sosyal destek kimler tarafindan sağlanıyor? (Birey hangi sosyal destek mekanizmalarına sahip? Ya da birey hangi sosyal ağlar üzerinden sosyal destek elde etmektedir?)

- Bireyin sahip olduğu sosyal destek türleri nelerdir? (Birey sosyal ilişkileri içinde hangi destekleri elde ediyor? Bireyin sosyal sermaye potansiyeli nasıl?) 
- Sosyal destek bireyin yaşamında hangi etkiye sahip? (Sosyal desteğin birey yaşamına sağladığı kazanımlar nelerdir?)

Bu sorular birey- sosyal destek ilişkisini anlamlandırmada, başka bir ifade ile bireyin sosyal sermaye ve sosyal destek potansiyelini anlamlandırmada odaklanılması gereken hususlardır. Pratikte bu soruların aydınlatılabilmesi için ise, sosyal sermaye, sosyal ağlar ve sosyal destek teorik perspektifine hâkim olmak gerekmektedir.

Sosyal destek konusuna bakıldığında, sosyal sermaye ve sosyal ağ teorileri önemli bir yer tutmaktadır. Sosyal sermaye teorisyenleri, birey, grup, toplum bazında sosyal sermayenin ölçülmesi, değerlendirilmesi için görüşler sunmuştur. $\mathrm{Bu}$ çalışmada birey- sosyal destek ilişkisi ele alındığından ötürü bireysel sosyal sermaye üzerinde durulacaktır.

Birey üzerinde odaklanılan sosyal sermaye teorilerine bakıldığında özellikle Bourdieu (1983), Coleman (1988) ve Lin'in (1986) görüşleri literatürde tartışılmaktadır. Sosyal sermayeyi sosyal ağlar üzerinden açıklayan ya da başka bir ifade ile sosyal sermayede başlangıç noktası olarak sosyal ağları alan teorisyenlere bakıldığında ise yine Coleman, Lin, Burt ve Granovetter'in olduğu söylenebilir. Özellikle Lin, Burt ve Granovetter'in sosyal kaynaklar, sosyal ağ kavramlarından sosyal sermaye getirilerine ulaştığı söylenebilir. Bu açıdan bakıldığında, sosyal sermaye tartışmalarında sosyal ağların niceliksel, niteliksel durumu ve bunu etkileyen faktörlerle elde edinilen sosyal sermaye potansiyeli ilişkisi sosyal sermaye tartışmalarında önemli bir yer tutmaktadır.

Sosyal sermaye teorilerinin öncülüğünü Bourdieu'nun yaptığı görülmektedir. Bourdieu'nun Marx’ın “sermaye” kavramını ödünç alarak, sermayenin sadece ekonomik bir değeri olmadığından hareketle, sermayeyi ekonomik, beşeri, kültürel, sosyal, simgesel sermaye olarak sınıflandırdığı çok boyutlu bir anlamlandırma çabası olduğu görülmektedir. Bourdieu sosyal alan içersinde bireylerin var olma çabalarını ve var olmalarını bu sermayelere ne kadar sahip oldukları ile ilişkilendirmiş ve sosyal alan içindeki eşitsizliklere odaklanmıştır.

Ona göre bireyler, sosyal alanda sahip oldukları güç, kaynak nispetinde sosyal alanda daha başarılı olmaktadırlar. Bu durum sosyal alanlar içerisindeki mücadele ortamını da nitelemektedir. Bireyler alanlarda sahip oldukları sermayenin azlığına veya çokluğuna göre sosyal alanda konumlanmışlardır. Herkes egemen pozisyonları arzuladığı için, sosyal uzam bir mücadele alanı olarak karşımıza çıkmaktadır. (Jourdain ve Naulin, 2011: 105). Sosyal sermaye bireyler için bir grubun üyesi olması yoluyla kurumsal kaynaklara ulaşmada aracılık etmektedir. Ona göre, bireyin bağlarının değeri; harekete geçirebildiği bağlantı sayısına ve her bir bağlantıyla sahip olunan (kültürel, sosyal ve ekonomik) sermaye büyüklüklerine bağlıdır (Field, 2008: 23). Bourdieu özetle, ekonomik, kültürel, sosyal, simgesel sermaye kavramlaştırmaları ile sosyal alan içindeki hiyerarşi sorununa odaklanmaktadır ve tüm sermaye gruplarının toplumsal eşitsizlikleri yeniden ürettiğini vurgulamaktadır. Sermayeyi sınıflandırmasıyla sosyal alan içerisindeki güç dengesinin ve tabakalaşmanın tüm yönleriyle anlaşılması gerektiğini savunmaktadır. 
Bourdieu'nun görüşlerini sosyal destek üzerinden okuduğumuzda iki noktanın önemli olduğunu görürüz. Birincisi bireylerin hangi sosyal ağlara sahip olduğu konusu, ikincisi ise bireylerin bağlantıda olduğu bireylerin de sosyal alandaki bu eşitsizlik ve mücadele alanından etkilendiği konusudur. Çünkü Bourdieu'ya göre elitler daha değerli sosyal kaynaklara sahiplerdir ve bu durum eşitsizliği pekiştiren bir unsur olarak karşımıza çıkmaktadır. Bu açıdan bakıldığında, Bourdieu’nun sosyal sermaye açılımı aslında bir yandan bireylerin elde ettikleri kazanımın hangi sebeplere bağlı olduğunu ve sosyal sermaye potansiyellerini açıklarken, diğer yandan sosyal alan içinde bireylerin sermaye kazanımlarının dengesizliğine vurgu yapmaktadır. Bu açıdan sosyal destekle bağlantılı olarak, Bourdieu'nun bakış açısı, sosyal desteğe diğer bireyler kadar erişimi olamayan bireyler için ne yapılması gerektiği hususunda bir katkıda bulunabilir.

Coleman'ın görüşlerine bakıldığında, Coleman sosyal sermayeyi birey- grup bazında değerlendirmiştir. Bireysel çıkarların önemine vurgu yapan Coleman diğer yandan gruba dahil olan her birey için ve grup için faydalarına değinmiştir. Coleman, sosyal sermaye birikimini gruptaki sosyal alışverişle birlikte formüle etmektedir. Çünkü ona göre bir grup üyesinin diğer bir kişiden yardım istemesi yükümlülük ve beklenti oluşturacaktır. Grup üyeleri arasında yükümlülük ve beklentinin oluşması ve devam etmesiyle sosyal sermaye potansiyelini artmakta ve sosyal sermaye yatırımı olarak bireye fayda sağlamaktadır. Diğer yandan eğer birey, ihtiyacını kendi kendine giderse ya da resmi bir kaynaktan yardım isteyerek ihtiyacını giderse bu grup üyesine herhangi bir yükümlülük oluşturmamasından ötürü topluluğun ödenmemiş sosyal sermayesine bir katkı sağlamayacaktır (Coleman, 2010: 113).

Coleman'ın sosyal sermaye anlayışında, bireylerin birbirleriyle sıkça temasta bulundukları yapılar, ortak davranış normları ortaya çıkartan ve bireylerin birbirlerine karşı beklentilerin oluşmasını sağlayan bir işlev yerine getirmektedir. Bu ilişki yapıları, düzenli temaslar ve davranış normları aracılığıyla aktörler arasında güven ve itibar inşa edilmesini ve böyle sosyal sermaye potansiyelini arttırmaktadır (Öztaş, 2007: 83). Coleman güçlü ilişkilerin ve sosyal ağların kapalılığının önemini belirtmiştir. Sosyal ağlardaki bu kapalılık güçlü bir sosyal kontrol ve norm oluşturmaktadır ve güveni grup içinde gerekli kılmaktadır.

Coleman'a göre, bazı sosyal yapılar sosyal sermaye oluşumunu kolaylaştırmaktadır. Ağlardaki kapalılık en belirgin şekilde Coleman tarafindan savunulmuştur. Coleman (1988) sosyal ağlardaki kapalılığın güveni, normları beslediğini dolayısıyla daha fazla sosyal sermaye açığa çıkardığını savunmaktadır. Coleman'ın formülasyonunda, eğer A kişisi B kişisi için bir şey yaparsa, ve A kişisi B'nin gelecekte bunun karşılığını vereceğine inanırsa, A kişisi beklenti içine girer, B kişisi için ise yükümlülük oluşur. Bu formulasyon özellikle kapalı ve daha küçük ağlarda düşünüldüğünde bireyler üzerinde dışsal etkiler oluşturmaktadır ve normları beslemektedir.

Coleman'ın sosyal sermaye teorisini sosyal destek üzerinden okuduğumuzda, grup içindeki sosyal alışverişi ve dolayısıyla sosyal destek alışverişini anlamlandırmada, özellikle aile, akrabalık, komşuluk, arkadaşlık gibi ilişki sistemlerindeki sosyal sermaye 
potansiyelini çözümlemede ve bu potansiyeli güçlendirmede Coleman'ın bakış açısının çok önemli olduğu söylenebilir. Diğerkâm kültürlerde dayanışmacı ruhun dinamiklerini anlamakta ve bireyler, gruplar için sosyal sermaye ve sosyal desteği anlamlandırmada Coleman'ın sosyal ağlara odaklanarak geliştirdiği bu teori sosyal sermaye teorilerine önemli bir açılım getirmiştir. Bu bağlamda sosyal destek, özellikle yakın ilişkilere sahip olunan sosyal ağlarda daha fazla potansiyele sahiptir. Grupta normların tüm üyeler tarafindan kabul edilmesi, bireylerin sosyal alışverişlerinde birbirlerine yeni yardım yükümlülükleri doğurarak karşılıklı yardım ilişkisinin beslenmesi hem grubun üyeleri için hem de grup için sosyal sermaye potansiyelini arttırmaktadır. Özellikle aile, akrabalık, komşuluk, arkadaşlık ilişkilerinde güçlü bağlara sahip olmak ve sosyal alışverişlerdeki sıklık bireylerin hastalıkla ilgili yardım gereksinimlerinde, bakım ihtiyacı söz konusu olduğunda, borç para alma durumunda önemli bir role sahip olduğu söylenebilir.

Coleman'dan sonra sosyal ağlara odaklanarak sosyal sermayeyi açıklayan diğer teorisyenler Lin (2001) ve Burt (2000) ve Granovetter (1973)'in olduğu söylenebilir. Coleman görüşlerinde sosyal ağların kapalılığını bir diğer ifadeyle dayanışmacı sosyal ağların öneminden bahsetmiş̧tir. Coleman bu görüşü savunurken, zayıf bağların önemini bir diğer ifadeyle zayıf bağlantıların önemi ise Burt ve Granovetter tarafindan savunulmaktadır.

Granovetter, (1973:1361) bir bağın gücünü, bağı oluşturan zaman miktarının, duygusal yoğunluğunun, samimiyetinin ve karşı1lıklı yükümlüklerin bir kombinasyonu olarak tanımlamıştır. Bu bağlamda güçlü bağlar, daha sık etkileşimde bulunulan, duygu yoğunluğunun, paylaşımın, yakınlığın daha güçlü olduğu ağlardır. Zayıf bağlar ise, daha az etkileşimde bulunulan ve buna bağlı olarak duygu yoğunluğunun daha zayıf olduğu ağlardır. Granovetter'e göre (1973:1362), ağlarda daha sık etkileşimde bulunma ve duygu yoğunluğunun fazla olması etkileşimde bulunan bireylerin birbirine benzerliğini ve bu bireylerin aynı davranış kalıplarını göstermelerine neden olmaktadır. Bunu bilişsel boyut ile açıklayan Granovetter, bireylerin sık ve yoğun etkileşimde bulunmalarından dolayı, bireyler uyum içersinde olmayı ve duygularının uyuşmasını ister. Zayıf ağlarda ise, bu uyum psikolojik olarak daha az beklenir. Dolayısıyla samimiyet derecesi düşük olan, daha nadir temasta bulunulan bireyler ağlara farklılık getirir. Bu farklılık daha faydalıdır, çünkü böylece hiç duymadığı bilgilere ulaşabilme imkânı oluşturur.

Zayıf ağlara sahip olan ilişkilerde, daha fazla ve her şeyden önce başka bir türde sosyal sermaye elde edilebilir. Daha yakın ilişkilerde ise, ağda bulunan bireylerin özellikleri birbirleriyle benzerdir. Yakın ilişkilerde önemli bir düzeyde kapalılık hâkimdir. Bu kapalılık dışardan yeni bireylerin ağlarla paylaşımda bulunması konusunda tutucudur. Zayıf ağlarda ise, farklı ağbağlardan köprü (Bridging) vasıtasıyla paylaşım söz konusudur. Putnam, bu durum için bonding ve bridging kavramlarını kullanmıştır. Bu iki kavram anlamsal olarak, zayıf ve güçlü bağlarla aynı içeriğe sahiptir. Bu durumda, zayıf ağlar köprülerin fonksiyonu aracilığıyla bilgilerin yayılabilmesi konusunda önemli bir role sahiptir (Windzio ve Zentarra, 2014: 55). 
Zayıf ağların mı ya da yoğun ağların mı bireye daha fazla sosyal sermaye kazanımı sağladığı tartışmasını Lin, zayıf ve yoğun sosyal ağların farklı farklı getirilerine dikkat çekerek başka bir noktaya taşımıştır. Bireylerin sosyal ağlarına bakıldığında, kimi kişi ve gruplarla daha sıkı ilişkiler kurulduğu (aile, akrabalık, yakın arkadaşlıklar vb.), kimi kişi ve gruplarla ise daha uzak bağlantılarla (iş, okul arkadaşlığı, patronla ilişkiler, üye olunan STK'daki ilişkiler vb.) ilişkiler kurulduğu görülür. Yakın ilişkilerde özellikle karşılaşılan zor durumlarda bireye ciddi duygusal destek ve yardımlaşma konusunda katk1 sağladığ1 görülürken, kişinin daha uzak bağlantılarından elde ettiği bilgi, yönlendirme, materyal destek kişinin güçlük durumunu aşabilmesinde ciddi yarar sağlayabilir. Lin'e göre kapalı ya da açık networkler gereklidir iddiasında bulunmaktansa, hangi getiriler ve hangi koşullar altında daha çok fayda sağlayacağı ve bu duruma göre ampirik inceleme ile belirtilmelidir (Lin, 2010: 184). Lin, Coleman'ın sosyal kapalılık teorisi ile Burt ve Granovetters'in zayıf ağların öneminden bahsettikleri teorileri bir konseptte toplamıştır. $\mathrm{Bu}$ bağlamda, bireyler, zayıf ağlarından araçsal eylemler için fayda sağlarlar. Daha uzak sosyal yapılardan zayıf ağlar dolayısıyla bilgi elde ederler. Böylece farklı sosyal yapılara sağladıkları üyelikle öncelikle sosyal yükselme elde edebilirler. Diğer yandan daha yoğun ağlardaki güçlü ilişkiler ifadesel eylemler için fayda sağlar. Yardımlaşma ve ilişkilerde karşılıklı olarak birbirini onaylama söz konusudur (Fuhse, 2016: 185).

Yakınlık ve yoğun iletişim kurmanın bireyin duygusal destek sağlaması anlamında özellikle bireyin problemli zamanlarında ve bireyin genel iyilik haline yansıyan, bireyi güçlendiren bir unsur olduğu bilinmektedir. Bireyler karşılaştıkları problemlerde yakın ilişkilerinden sadece duygusal destek almazlar. Daha özel problemlerini daha yakınlarındaki insanlarla paylaşarak bu problemlerine çözüm arayabilirler ve problemlerinin çözümüne ilişkin daha yakın ilişki kurduğu insanlardan problemin çözümüne ilişkin bilgi edebilirler. Bu durum aslında araçsal ve ifadesel eylemlerin birbirinden kesin çizgilerle ayrılamayacağını aksine birbirlerini tamamladıklarını göstermektedir.

Lin'in sosyal ağlara yaklaşımı, sosyal destek konsepti ile uyum göstermektedir. Sosyal desteğin sosyal ilişkiler içerisinde elde edildiği düşünüldüğünde, bireylerin genel iyilik haline etki eden sosyal destek ve bireyin zor durumlarında güçlenmesine etki eden sosyal destek ancak bireyin tüm sosyal ağlarından fayda sağlaması ile mümkün olmaktadır. Bireyin dezavantajlı bir konumda olmasından dolayı stratejik bir konumda olan bireyle bağ kurması onun iş bulmasına, terfi almasına neden olabilir. Fakat aynı dezavantaja sahip bireyin ailesinin dağılması, eşinden ayrılması söz konusu olduğunda sorununu paylaşarak rahatlayacağı, sarılacağı güçlü yakın ilişkilere de ihtiyacı vardır. $\mathrm{Bu}$ bakımdan hangi koşullar için hangi sosyal ağlar soruları bireyi için önemlidir. Nitekim sosyal destek sadece manevi anlamda bireyi güçlendiren unsur değildir. Sosyal desteğin maddi boyutu da mevcuttur. Sosyal desteğin boyutlandırılması bu bağlamda hangi sosyal ağlardan (heterojen veya homojen) hangi sosyal desteklerin sağlanacağı ya da başka bir ifadeyle sosyal ağların sosyal destek potansiyellerinin belirlenmesi bizlere daha net bir görüntü verecektir. 
Sosyal desteğe sosyal sermaye ve sosyal ağlar teorileriyle yaklaşıldığında, öncelikli olarak sosyal desteğin keşfedilmesinde, sosyal desteğe erişimde, sosyal destek kaynaklarının belirlenmesinde, sosyal desteğin analizinde, sosyal destek potansiyelinin arttırılmasında, sosyal destek kaynaklarının güçlendirilmesinde ve sosyal destek getirilerinin bireye hangi imkânları sağladığı konusunda anlamlı bilgilere ulaşılmaktadır. Sosyal desteğin birey hayatı için önemi, sosyal desteğin bireyin hayatına ne getirdiği, bireye ne sağladığı sorusu ile özetlenmesi mümkün değildir. Bu soru sosyal sermaye ve sosyal ağ kuramlarının sağladığı teorik perspektifle ancak tam olarak cevaplandırılabilir.

\section{Sosyal Destek, Sosyal Hizmet için Neden Önemlidir?}

Sosyal destek, sosyal hizmet için neden önemlidir sorusunun cevabını öncelikli olarak sosyal hizmet uygulamasının gereksinimleri açısından cevaplamak gereklidir. Başka bir ifade ile uygulamaya etki eden, uygulamayı şekillendiren sosyal hizmetin teorik perspektifi ile sosyal desteğin neden önemli olduğu konusu aydınlatılmalıdır.

Birey- sorun- çevre etkileşimi sosyal hizmet uygulamalarında Genelci Yaklaşım, Ekolojik Yaklaşım ile soruna etki eden ve sorunun çözümüne yardım potansiyeli olan her türlü çevresel etkenin değerlendirilmesini zorunlu kılmaktadır. Bireyi çevresi içinde değerlendirmek bu bağlamda hem sorunun tespitinde hem de sorunun çözümünde önemli bir yere sahiptir. Diğer yandan sosyal hizmet, Güçlendirme Yaklaşımı ile bireyin güçlü yanlarını sosyal hizmet uygulamasına dâhil etmek, kendi kendine yardım prensibini benimsemektedir. Sosyal hizmet uygulamasını etkileyen bu teorik yaklaşımlar, sosyal çevre- birey- sorun etkileşiminde sosyal destek kaynaklarının keşfini, analizini gerekli kılmaktadır.

Genelci yaklaşım, bireyin yaşadığı sorunun kendisinden kaynaklandığı görüşünü destekleyen medikal yaklaşımları eleştirerek birey- sorun- çevre ilişkisinin kurulmasının gerekliliğini savunmaktadır. Şahin'e göre (2002:3) sosyal hizmetin amacı, insanların yaşam içinde sosyal rollerini yerine getirmeleri ve karşılaştıkları sorunlar ile baş edebilmeleri için yeteneklerini geliştirmek, insan ihtiyaçlarını yeterli ölçüde karşılanmasına olanak veren çevresel imkânları artırmaktır. Sosyal hizmetin mesleki etkinliğinin odağı, bireyin sosyal işlevselliği ve çevresi ile olan etkileşimi çerçevesinde değişme ajanlığıdır. Ekolojik yaklaşıma bakıldığında ise, bireyin temasta bulunduğu tüm sosyal sistemlerle etkileşime girilerek soruna etki eden unsurların ortaya çıkarılması vurgulanmaktadır. Bu yaklaşım çevre birey etkileşimini dinamik bir süreç olarak ele almakta ve bireyleri bu etkileşimde aktif olarak görmektedir. Bu bağlamda bir sosyal hizmet uygulamasında, müdahalenin bireye yönelik değil tüm ekolojik birime yöneltilmesini savunur (Duyan, Sayar, Özbulut, 2008: 52). Bu açıdan bakıldığında, soruna etki eden tüm unsurların ortaya çıkarılması ancak birey- çevre etkileşiminin tam olarak anlaşılması ile mümkün olmaktadır.

Sosyal desteğin, bahsedilen çevre etkileşiminde nerede durduğuna bakıldığında, öncelikle bireyin iletişim kurduğu sosyal ağların odak alınan sistemlerden biri olduğu ve soruna etki eden unsurların en önemlilerinden olduğu unutulmamalıdır. Bireyin sosyal 
kaynaklarının belirlenmesi ve kurduğu ilişki düzeyi ve niteliği bu bağlamda soruna etki eden unsur olarak değerlendirilmelidir. Diğer yandan var olan sosyal kaynak düzeyinin yanında yetersiz sosyal kaynak durumu da, bireyin sorununu pekiştiren, bireyin sorun çözme kapasitesini olumsuz etkileyen bir unsur olarak ele alınmalıdır. Bu açıdan bakıldığında, tüm sosyal kaynakların belirlenmesi öncelikle ilişkinin durumunun ve düzeyinin tam olarak anlaşılması için gereklidir. Fakat eksik sosyal kaynak durumu da bireyin sorunla baş etme kapasitesini etkileyen bir faktördür. Sosyal sermaye ve sosyal desteğin bireye sağladığ 1 faydalar düşünüldüğünde, bu kaynaklara sahip olamayan bireyler için sosyal hizmet benimsediği sosyal adalet ilkesi gereği eylemde bulunmalıdır.

Bireyin kaynak durumu özellikle Güçlendirme Yaklaşımının perspektifinden bakıldığında daha fazla anlam taşımaktadır. Bilindiği gibi, Güçlendirme Yaklaşımı, probleme ve bireyin güçsüz yanlarına, patolojiye vurgu yapan medikal yaklaşımları eleştirerek, bireylerin güçlü yanlarına ve bireylerin kaynaklarına vurgu yapmaktadır (Duyan, Sayar, Özbulut, 2008: 61). Bireyin güçlü yanlarının neler olduğu, kaynaklarının neler olduğu bu bağlamda sorulması ve belirlenmesi gerek en temel sorulardır. Sosyal hizmet açısından bireyin kaynakları, bireysel kaynaklar (kişisel yetkinlikler, yetenekler vb.), sosyal kaynaklar (sosyal ağlar ve profesyonel destek hizmetleri), materyal kaynaklar (finansal destek, maaş, konut vb.) olarak ele alınabilir. Sosyal hizmette bireyin kaynaklarının belirlenmesi ve sistematik kullanımı yardım planının bir parçasını oluşturmaktadır (Möbius, 2010: 14).

Sosyal destek, psikolojik, bilişsel, araçsal yardım boyutuyla bireyin problemle başa çımasında birçok olumlu etkiye sahiptir. Sosyal hizmet ise, bireyin problemlerini çözmeyi ve bireyin sorunlarla baş edebilecek kapasitelerini geliştirerek sorunlarla başa çıkması için bireyi güçlendirmeyi hedeflemektedir. Kendi kendine yardım ilkesini benimseyen profesyonel sosyal çalışma, bireyin sosyal eksikliklerini dengelemeyi, toplumsal hayata entegrasyonu ve sosyal hayata katılımı kolaylaştırmayı da mümkün kılmaya çalışır. Bu entegrasyon mikro ve mezzo düzeyde sosyal ağlara katılımla gerçekleşir. Eğer bireyin sosyal ağlarında sosyal eksiklikler mevcutsa, enformel sosyal destek olanakları azalır ve birey kriz durumlarında sosyal çalışma gibi mesleki yardım kaynaklarına bağımlı kalır (Barth, 2015: 32). Sosyal kaynak yetersizliği ya da başka bir ifade ile sosyal destek yetersizliği görüldüğü gibi, bireyin sorun çözme kapasitesini etkileyen en önemli unsurlardan biri olarak değerlendirilmektedir. Sosyal ağlardaki eksiklik, sosyal desteğin araçsal, psikolojik, bilişsel boyutlarıyla düşünüldüğünde, bireyin sosyal ağlarından elde edemediği tüm destekler için profesyonel kurumlara başvurmalarını gerektirir.

Sosyal hizmet için sosyal ağlar, sosyal destek ilişkisi, hem eksik kaynakların belirlenmesi hem de var olan sosyal kaynaklarının durumunun, bireye etkisinin belirlenmesi ve iyileştirilmesi için sosyal hizmet uygulamalarında dikkatlice irdelenmesi gereken hususlardan birini oluşturmaktadır. Nitekim sosyal hizmet uygulamasını etkileyen teorik arka plan ve mesleğin benimsediği ilkeler düşünüldüğünde, bireysorun- çevre etkileşiminin önemine vurgu yapıldığı görülmektedir. 


\section{Sosyal Hizmet Uygulamalarında Sosyal Destek Analizi için Bir Model Oluşturulabilir mi?}

Sosyal çevre- birey etkileşimi sosyal hizmet uygulamasında müdahalenin odağında yer almaktadır. Nitekim bireyle görüşme esnasında sosyal inceleme raporunda müracaatçının iletişimde olduğu bireyler hakkında genel bilgilere yer verilir. Bireyin özellikle ailesinin ilgisi, yakın ilişkide olduğu bireylerden sağladığı destekler gibi konulara yer verilir. Ama bunun bir yönteme, modele bağlı kalmadan genel düzeyde yapıldı̆̆ 1 söylenebilir.

Detaylı bir sosyal ağ çalışmasının sosyal hizmet uygulamasına entegre edilmesi, hem sosyal çalışmanın yukarıda bahsedilen teorik yaklaşımların "çevre- sorun- birey" vurgusu düşünüldügünde, soruna ve sorunun çözümüne yardım eden etkenlerin tam olarak belirlenmesi açısından, hem de sosyal destek bireyin sahip olduğu kaynak, güç olarak ele alındığında, bireye sağladığı yardımlar, avantajlar açısından düşünüldüğünde gerekliliği görülmektedir. Bireyin çevresi, sosyal ağları hakkında daha sistematik bilginin elde edilmesi ve sosyal hizmet uygulamasına dahil edilmesi bireyin sorun ortadan kalktıktan sonra da genel iyilik halini etkilemesi bakımından oldukça önemlidir.

Sosyal ilişkiler içinde elde edinilen sosyal destek, sosyal ilişkilerin niteliksel ve niceliksel özelliklerini barındırması açısından gayet kompleks bir yapıdan oluşmaktadır. Sosyal sermeye ve sosyal ağ teorilerinde ortaya koyulan görüşlere bakıldığında, sosyal destek potansiyelini etkileyen birçok faktör mevcuttur. Bireyin ilişkide olduğu sosyal yapının özellikleri, bu yapının üyelerinde mevcut gömülü kaynaklar, ilişkinin dayanışma özellikleri taşıması ya da tam tersi daha zayıf ilişkiler içinde olmak gibi birçok faktör sosyal destek potansiyelini etkilemektedir.

Sosyal destek potansiyeli ancak ilişkilerin başka bir ifadeyle bireyin sahip olduğu sosyal ağların analiz edilebilmesi ile mümkün olmaktadır. Bireyin sosyal ağlarındaki bireylerle ne kadar sıklıkla görüştüğü, yakınlık hissiyatı, problem çözmede destek, duygusal paylaşımı, daha önce aralarındaki yardımlaşma ilişkisi gibi durumlar ilişkinin nicel ve niteliksel özelliklerinden bazılarıdır. Bu açıdan bakıldığında sosyal destek ilişkisi karşılıklı değiş tokuş ilişkisi içersinde olmaktadır ve sosyal alışverişi yansıtmaktadır. Bu sosyal alışveriş ise bazı durumlardan etkilenmektedir (Diewald ve Sattler 2010: 689693). Bu durumlar, bireylerin sosyal destek vermeye istekli olmamaları, bireylerin bazı kaygılardan ötürü yardım ilişkisi kurma isteğinde olmaması ya da yardıma ihtiyaçları olduklarında çevresindeki kaynakları değerlendirme kabiliyetlerine sahip olamamaları ve kültürel etmenler olarak sayılabilir. Görüldüğü gibi bireyin sahip olduğu sosyal ağlardaki sosyal destek potansiyelini kullanması bile birçok faktörden etkilenmektedir. Özellikle kriz durumlarında veya bireylerin bir sosyal sorunla karşılaştıklarında, mevcut sosyal sermaye ve sosyal destek potansiyellerini harekete geçirme noktasında etkisiz kalırlar. Bu durumlar, sosyal desteğin sosyal çalışmaya dahil edilmesi ve bireyin sahip olduğu bir güç olarak bir kaynak olarak kullanılması için bir modele ihtiyaç olduğunu göstermektedir. 
Sosyal çalışma, bireyin hayatını güçleştiren bir problemle karşılaşması durumunda bireyin problemini çözmesini desteklemek için ya da günlük hayatında bireyi güçlendirmek maksadıyla üç çalışma alanına odaklanır (Möbius, 2012: 107):

- Materyal kaynaklar düzeyi (yaşam yeri güvencesi, gelir düzeyi, temel bakım).

- Ağlara aktif katılım düzeyi (sosyal ağ durumu, günlük ve kriz durumlarında sosyal destek düzeyi).

- Bireysel kaynakların teşviki ve tespiti (bir amaca ulaşmada gerekli olan yetenekler, beceriler).

Literatürdeki adıyla, sosyal ağ çalışması ya da başka bir ifade ile sosyal ağlara odaklanan sosyal çalışma, sosyal desteğin analizinde etkili bir model olarak görülmektedir. Burada amaç sadece bireyin sosyal destek potansiyelinin değerlendirilmesi ile sorun çözmeye dahil edilmesi değildir. Sosyal çalışma, aynı zamanda bireyin sosyal işlevselliğini arttırmaya çalışmaktadır. Sosyal ağ potansiyelinin artması, bireyin genel iyilik halinin artmasında, kendisini güvende hissetmesi, sevilme ihtiyacını gidermesi gibi ihtiyaçlar açısından düşünüldüğünde bireyin refahına ve ferahına katkıda bulunacaktır.

Sosyal ağlar üzerine odaklanılan sosyal çalışmada şu noktalar ön plana çıkabilir:

- Eksik sosyal kaynakların (eş, aile-akraba, arkadaş tanıdık, komşuluk) dönüşümü

- Yeni ilişki kalıpları oluşturmak

- Sosyal kontaktları iyileştirmek

- Psiko-sosyal kaynakların daha iyi kullanımı ve aktifleştirilmesi (Pelzer, Renate 2004S.3).

Sosyal ağ çalışmasında belirli aşamalarla ilerlenir. İki aşamada sosyal ağ çalışması şu şekilde özetlenebilir (Friedrich, 2012: 63 ):

1. Sosyal Ăg ve Sosyal Destek Analizi: Öncelikle bireyin iletişim içinde olduğu akraba, arkadaş, iş-okul arkadaşlığı, komşular ve profesyonellerin listesi belirlenir ve bu ağ grupları kâğıt üzerinde görünür hale getirilir. Ağ kartları (Netzwekkarte) müracaatçı tarafindan, verilen şemada kendisine uzaklıkyakınlık ilişkisine göre doldurulur (Freidrich, 2012: 67-68). 


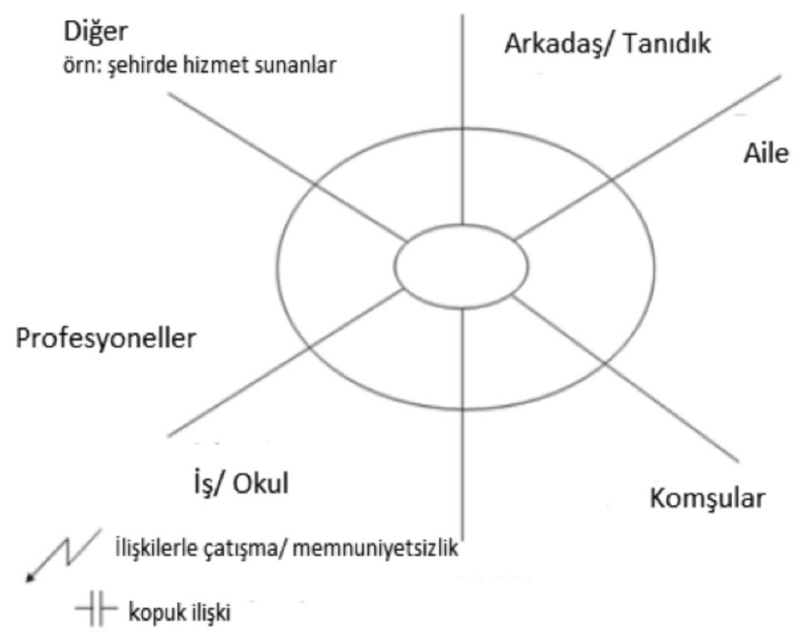

Şekil 1

Ă̆ Kartları Kaynak: Friedrich (2012: 68)

Birey (ego) ortada yer alır. Ağ kartları aracılığıyla bireyin farklı yaşam alanlarındaki ilişkide olduğu gruplar ya da anlaşmazlık potansiyeli olan bireyler listelenir. Ağ kartlarını, sosyal destek analizi takip eder. İsimleri yer alan bireylerin destek potansiyelleri ve müracaatçının bu ilişki içindeki destek verme imkânı belirlenir. Özetle, ne dereceye kadar belirtilen alanlarda destek alınıp verildiği incelenir. İlişkilerin karşılıklı yapıları düşünüldüğünde destek yapılarını anlamak açısından ilişkilerdeki sosyal destek düzeyinin karşılıklı (desteği alan- desteği veren) incelenmesi önemli bulunmaktadır. Sosyal destek düzeyi dört alanda belirlenir: duygusal günlük destek (dinleme-paylaşım), pratik günlük destek (taşınma, çocuk bakımında yardım, yol göstermek), duygusal kriz desteği (teselli/ cesaretlendirme) ve pratik kriz desteği (borç para vermek). Ayrıca şema üzerinde bunların dışında boş bırakılan alanlara diğer alınan ya da verilen desteklerin yazılması istenir (Freidrich, 2012: 67).

Diğer yandan bireyin sosyal ağ kaynakları değerlendirilirken, bireyin kaynakları da değerlendirilerek, sorunun çözümünde bütüncül bir bakış açısı sağlanır. Bireyin kaynakları, sorun çözme aşamasında bireyin güçlü yanlarından oluşmaktadır. 


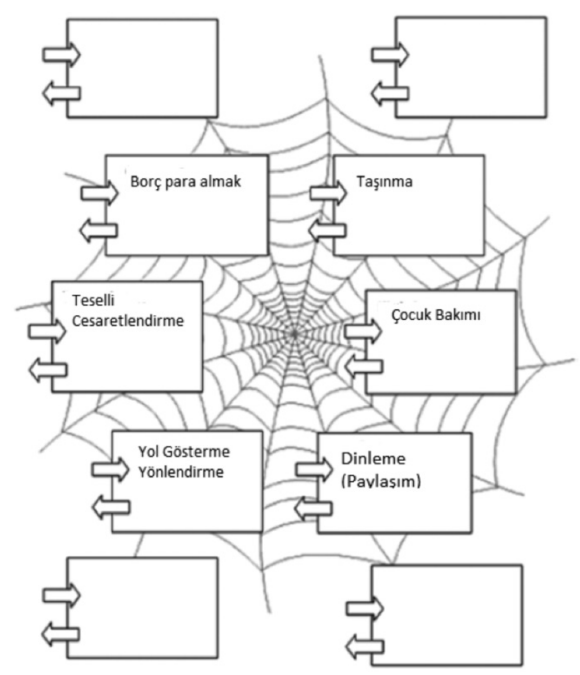

Şekil 2

Sosyal Destek Kartlarl Kaynak: Freidrich (2012: 71)

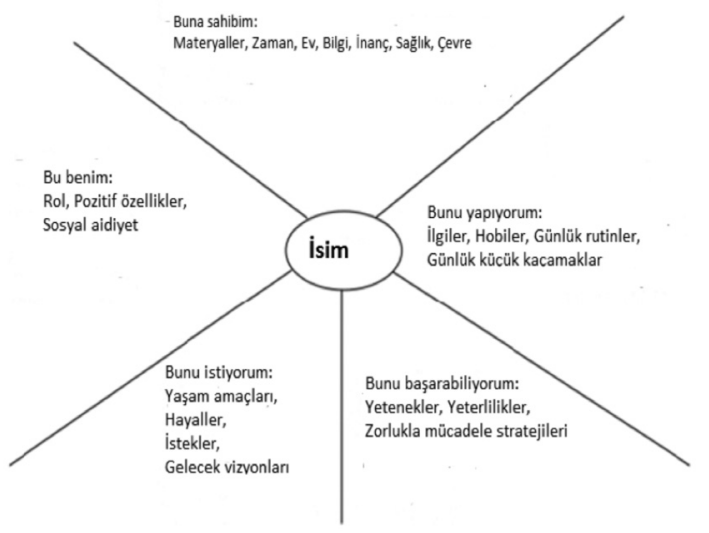

Şekil 3

Bireyin Kaynak Kartları Kaynak: Freidrich (2012: 73)

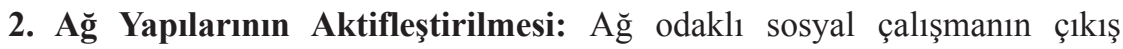
noktası, bireylerin sosyal ağlarını genişletmek ve sosyal destek potansiyelini arttırmak ya da var olan sosyal destek potansiyelinin bireyler tarafindan nasıl 
daha iyi kullanılacağını belirlemektir. (Freidrich, 2012: 63) Sosyal ağ odaklı danışmanlık bu görevi görür.

Ancak her durum için ağ odaklı bir sosyal çalışma uygulama planı yoktur. Bazı durumlar için söz konusudur ve bireyin kontrolündedir. Bunun dört adımı vardır. Öncelikle amaç belirlenir ve somutlaştırılır. Bu amaca ulaşmada, hangi sosyal ağların mobilize edilebileceğine bakılır. İkinci adımda, amaca ulaşmada somut adımlar belirlenir ve "Kim sana yardım edebilir ve nasıl?" sorusunun yardımıyla bireyin enformel sosyal ağları eylem planına dahil edilir. Üçüncü adımda, risk kontrolü yapılır. Dördüncü adımda ise, amaçlara ulaşma ile mevcut durumun değerlendirilmesi yapılır (Freidrich, 2012: 76-77).

$\mathrm{Bu}$ yöntemin uygulanması için en önemli ön şart, müracaatçının mevcut sosyal ilişkileri hakkında sosyal çalışmacı ile birlikte düşünme motivasyonun olmasıdır. Bu yöntem sosyal çalışmacının veri toplama yöntemi olarak düşünülmemeli, müracaatçının sosyal ağlarının özellikleri üzerine veya sosyal ağlarla ilgili yaşanan tecrübeleri örneğin süren iletişim ağlarını ya da kopuk sosyal ağları müracaatçı ile birlikte görmek için bir yöntem olarak algılanmalıdır (Kaehler, 1983: 270). Sosyal ağlara odaklanan sosyal çalışma, bu bağlamda özellikle aktif olmayan bağlantıları harekete geçirme ya da bireyin mevcut sosyal kaynaklarını farkında olamama durumunda bireye profesyonel destek sağlamaktadır. Bunun yanında, çalışmada belirtilen sosyal destek kaynaklarının bireye sunduğu olanaklar düşünüldüğünde, eksik sosyal kaynak durumunda bireyin sosyal ağlarını güçlendirici çalışmalar da içermesi bakımından sosyal sermayenin faydalarının paylaşımında bireylere profesyonel destek sağlamaktadır

\section{Sonuç}

Sosyal desteğin bireyin yaşamı için önemi bireyin genel iyilik haline katkısı, bireyin sosyal bir sorunla karşılaştı̆̆ında problem çözme kapasitesini arttırması ve gelecekte oluşacak problemleri önlemesi açılarından ele alınmaktadır. Bireyin genel iyilik halini, sosyal işlevselliğini iyileştirmeyi ve bireyin karşılaştıkları sorunlarda yardımı amaçlayan bir meslek olan sosyal hizmetle sosyal destek bu anlamda önemli bir alanda kesişmektedir.

Sosyal hizmetin birey- sorun- çevre etkileşimine odaklanarak, hem soruna etki eden çevresel koşulların belirlenmesi hem de sorunun çözümüne etki edebilecek bireysel kaynakların belirlenmesi hususunda sosyal incelemelerde bulunduğu bilinmektedir. Nitekim odaklandığı alanlardan biri de, bireyin ilişkisel yapılarıdır. Bireyin sahip olduğu sosyal ağlar, soruna etki eden ve sorunun çözümüne etki eden en önemli nedenlerden biridir. Bu durum bireyin sosyal ağları hakkında daha sistemli bilgiye ihtiyaç olduğunu göstermektedir. Diğer yandan bireyin çevre ile uyumunu artırmaya çalışırken aynı zamanda kendi kendine yardım ilkesini benimseyen sosyal hizmet, bireyin sahip olduğu güçlü yanların da müdahaleye katılmasını amaçlar. $\mathrm{Bu}$ durumda bireyin bilincinde 
olduğu sosyal kaynaklar ve sosyal ağlarında gömülü olan kaynaklar ortaya çıkarılmalı, sosyal hizmet müdahalesine dahil edilmelidir. Diğer yandan sosyal adaleti ilke edinen sosyal hizmet, yeterli sosyal kaynaklara sahip olmayan dolayısıla sosyal kaynakların sağladığı kazanımlardan mahrum olan bireyler için de eylem de bulunmalıdır.

Sosyal sermaye, sosyal ağ teorileri bireylerin sosyal ağları üzerinden elde ettikleri potansiyel kazanımlara odaklanmakta ve kimi zaman bireyin üyesi olduğu sosyal yapının avantajlılığını- dezavantajılığıını değerlendirerek sosyal yapının sunduğu imkan ya da imkansizlıklara odaklanmakta kimi zaman da bireyin eylem gücü üzerinde durarak ilişkilerin niteliksel ve niceliksel özelliklerine vurgu yaparak ağlar üzerinden elde edinilen kazanımları açıklamaktadır. İnsan ilişkilerindeki karmaşıklık da düşünüldüğünde, sosyal desteği alan ve sosyal desteği veren bireylerin bu sosyal alışverişi birçok etmenden etkilenmekte ve analizin sistemli bir şekilde yapılmasını zorunlu k1lmaktadır.

Günümüzde Türkiye'de standart sosyal inceleme raporlarında, soruna etki eden bireylerle ilişki durumu, bireylerin çevrelerinden yardım alma, çevreleriyle ilişki durumu gibi hususlara yer verildiği görülmektedir. Fakat daha sistemli bir bilginin elde edilmesi için bir modele ihtiyaç olduğu söylenebilir. Bu çalışmanda bireysel sosyal sermaye ve sosyal ağ kuramları sosyal destek teorik alt yapısı ile ilişkilendirerek, sosyal hizmet uygulamalarında bireylerin sosyal destek potansiyelini belirlemede bir modelin gerekliliği üzerinde bilinç uyandırmak amaçlanmıştır. Çalışmada, sosyal ağ çalışmasının, sosyal hizmet uygulamalarına entegre edilmesi durumunda, bireylerin sosyal destek potansiyelinin belirlenmesi, sosyal destek potansiyelinin arttır1masi böylece bireylerin hem sorunla baş etme kapasitesini arttırma hem de bireylerin sosyal işlevselliklerin iyileştirilmesi konusunda katkı sağlayacağı savunulmaktadır.

\section{Kaynakça}

Abay Alyüz S. B. (2018). Sosyal Sermaye, Sosyal Ağlar ve Sosyal Destek İlişkisi- Sultanbeyli ve Kadıköy'de Sosyal Hizmet Merkezine Başvuranlara İlişkin Karşılaştırmalı Durum Çalı̧̧ası. Yalova Üniversitesi. Yayınlanmamış Doktora Tezi. Yalova.

Barth, S. (1998). Soziale Netzwerke und Soziale Unterstützung. http://www.stephanbarth.de/ Homepage-Aufsaetze/Soziale\%20Unterstuetzung.pdf. Erişim Tarihi: 20.04.2015.

Barth, S. (2015). Soziale Unterstützung In: Theorie und Praxis der Sozialen Arbeit, Heft 4S. (1-33).

Bullinger, H. ve Nowak, J. (1998). Soziale Netzwerkarbeit Eine Einführung für soziale Berufe. Freiburg: Lambertus.

Bourdieu P. (1983). Ökonomisches Kapital, kulturelles Kapital, Soziales Kapital. In R. Kreckel, Soziale Ungleicheiten (Soziale Welt Sonderband2) (183-198), Göttingen.

Bourdieu, P. (2010). Sermaye Biçimleri. Sosyal Sermaye Kuram Uygulama Eleştiri. Mehmet Murat Şahin, Ahmet Zeki Ünal (Der.). Sakarya: Değişim Yay. 
Burt, R. (2000). The Network Structure Of Social Capital Research in Organizational Behaviour. 22(1). (345-423).

Coleman J. S (1988) Social capital in the Creation of Human Capital. The American Journal of Sociology, 94, Supplement: Organizations and Instituations: Sociological and Economic Approaches tothe Analydid of Social Structure, (95-120).

Coleman, J. S. (2010). Beşeri Sermayenin Yaratımında Sosyal Sermaye. Sosyal Sermaye Kuram Uygulama Eleştiri. Mehmet Murat Şahin, Ahmet Zeki Ünal (Der.). Sakarya: Değişim Yay.

Cassel, J. (1976). The Contribution of Social Enviroment to Host Resistance, The Johns Hopkins University School of Hygiene and Public Health, 104(1). USA.

Diewald M. ve Sattler S. (2010). Soziale Unterstützungsnetzwerke Stegbauer C. ve Haeussling R.(Hrsg.) In: Handbuch Netzwerkforschung 689-699.

Duyan V., Özgür Sayar. Özbulut M. (2008) Sosyal Hizmeti Tanımak ve Anlamak. Sosyal Hizmet Uzmanları ve Sosyal Hizmet Alanında Çalışanlar için bir Rehber. Sosyal Hizmet Uzmanları Derneği. Ankara.

Eisemberger, D. (2010). Einfluss sozial- und baustruktureller Faktoren auf nachbarschaftliche Beziehungendargestellt am Beispiel der Großstadt Wien. (Yayımlanmış Yüksek Lisans Tezi) Viyana Üniversitesi. Viyana.

Erlemeier, N. (1995). Soziale Unterstützung bei der Auseinandersetzung älterer Menschen mit Belastungen. In A. Kruse \& H. Schmitz-Scherzer (Hrsg.). Psychologie der Lebensalter (253161). Darmstadt.

Field, J. (2008). Sosyal Sermaye. (Çev.: Bahar Bilgen, Bayram Şen). İstanbul: İstanbul Bilgi Üniversitesi Yay.

Friedrich, S. (2012). Ressourcenorientierte Netzwerkmoderation, Ein Empowermentwerkzeug in der Sozialen Arbeit, VS Verlag für Sozialwissenschaften | Springer Fachmedien lWiesbaden.

Fuhse, J. (2016). Soziale Netzwerke: Konzepte Und Forschungsmethoden. UTB. Deutschland.

Granovetter, M. (1973). The Strength Of Weak Ties. American Journal of Sociology. 78(6). (13601380).

House B. (1981). Work Stress and Social Support. Reading, MA: Addison- Wesley.

Jourdain, S. ve. Naulin, A (2011). Pierre Bourdieu'nün Kuramı Ve Sosyolojik Kullanımları. (Çev.: Öykü Elitez). İstanbul: İletişim Yay.

Paulinger, G. (2012). Soziale Unterstützung als Sozialkapital, Einwurf eines Frageninstruments für soziale Ressourcen. (Yayımlanmış Yüksek Lisans Tezi). Viyana Üniversitesi. Viyana

Pfingstmann, G. B. (1987). Untersuchungsverfahren zum sozialen netzwerk und zur Sozialen Unterstützung. İçinde. Zeitschirfft für Diffenrentielle und Diagnostische Psychologie. 8(1). (7598).

Kaufmann,F.(1988).NetzwerkbeziehungenvonFamilien.MaterialienzurBevölkerungswissenschaft. Sonderheft 17(1). Wiesbaden.

Kaehler, H. D. (1983). Ressourcen aus dem sozialen Netzwerk zur Bewältigung von schwierigen Alltagssituationen, Ergebnisse aus einer Erkundungsstudie. In: Neue Praxis 13 (1983), 3, pp. 262-272 
Lin N. (1986). Conceptualizng Social Support. In N. Lin ve Dean A, Ensel M. Social Support, Life Events, and Depression (17-30). Newyork: Acedemic Press.

Lin, N. (2001). Building a Network Theory of Social Capital In Lin N, Cook K ve Burt R.S. Social Capital Theory and Research(3-29) Newyork: Adline de Gruyter.

Lin, N. (2010). Sosyal Sermaye Network Kuramının İnşası. Sosyal Sermaye Kuram Uygulama Eleştiri. Mehmet Murat Şahin, Ahmet Zeki Ünal (Der.). Sakarya: Değişim Yay.

Möbius, T. (2010). Ressourcenorientierung in der Sozialen Arbeit, Möbius T und Friedrich S. İçinde. Ressourcenorientiert Arbeiten Anleitung zu einem gelingenden Praxistransfer im Sozialbereich. (13-30).

Öztaş, N. (2007). Sosyal Sermayenin Ağbağ Kuram(lar)1: Dayanışmacı ve Aracı Soysal Sermaye. Amme İdare Dergisi, 40(3). (79-98).

Sommer, G. Ve Fydrich, Th. (1989). Soziale Unterstützung. Diagnostik Konzepte. Tübingen.

Şahin, F. (2002). Genelci Sosyal Hizmetin Doğuşunu Hazırlayan Etmenler. Sosyal Hizmet Eğitiminde Temel Yaklaşımlar (Sosyal Hizmet Sempozyumu 18-19 Ekim 2002). Ankara.

Unger, D.G. ve Powell, D.R. (1980). Supporting families under stress: The role of social networks. Family Relations 29(1). (566-574).

Windzio M. ve Zentarra A. (2014). Die kleine Welt der starken und schwachen Bindungen. Der Beitrag der Sozialkapital - und Netzwerktheorie zur İntegrationsforschung. E.Bicer et al In: Soziale Netzwerke, Sozialkapital und ethnische Grenzziehungen im Schulkontex, Springer Fachmedien Wiesbaden. 